DOI: $10.31393 /$ reports-vnmedical-2020-24(4)-20

UDC: $616-083.98-089.5$

\title{
CYSTATIN C LEVEL AS A PROGNOSTIC RISK FACTOR FOR POSTOPERATIVE COMPLICATIONS IN ELDERLY PATIENTS
}

Rasenko A. V.

Kharkiv National Medical University (4, Science Ave., Kharkiv, Ukraine, 61022)

Responsible for correspondence: e-mail: rasenko1992@ukr.net

Received: September 21, 2020; Accepted October 29, 2020

Annotation. An important criterion for assessing the course of urgent surgical pathology in elderly patients is the concomitant state of sarcopenia. Decreased blood levels of cystatin C, which correlates with decreased muscle mass and strength, is an important screening criterion for perioperative intensive care therapy in these patients. The aim of the study was to increase the effectiveness of intensive care in patients with low sarcopenic index by improving the methods of influencing perioperative risk factors. We examined 90 elderly patients (73.3 \pm 7.9 years) with surgical pathology of the abdominal cavity, who underwent emergency surgery under general anesthesia based on sodium thiopental with artificial lung ventilation. Patients were divided into 3 randomized groups by age, sex, anthropometric data, volume and duration of surgery, concomitant comorbid background and perioperative intensive care: group I $(n=30)$ - patients undergoing standard intensive perioperative therapy, group II $(n=30)$ - standard intensive care with the addition of levocarnitine; group III ( $n=30)$ - standard intensive care with the addition of levocarnitine and a solution of $D$-fructose-1,6-diphosphate sodium salt hydrate. Muscle mass was determined by bioimpedancemetry on the analyzer "MEDASS" ABC-02, muscle strength was assessed by wrist dynamometry, muscle-skeletal mass index was calculated. The serum cystatin $C$ concentration was determined by latex-enhanced immunoturbidimetry (DIALAB GmbH, Austria). The significance of the obtained data was checked using the $r$ Pearson correlation coefficient. It is established that additional prescription of levocarnitine and D-fructose-1,6-diphosphate sodium hydrate salt significantly reduces the number of days of treatment in the intensive care unit, improves prognosis, and promotes early activation of patients. Metabolic changes caused by a decreased sarcopenic index require further research.

Keywords: sarcopenia, cystatin C, elderly age, surgical pathology, intensive care.

\section{Introduction}

With the introduction of "sarcopenia" term in 1989 by Irwin Rosenberg (to denote a decrease in muscle mass (MM) with aging) [10] and until 2010, there were no generally accepted criteria for making this diagnosis. The most commonly used quantitative criteria for sarcopenia, proposed by Richard Baumgartner et al. in 1998, which meant a decrease in $\mathrm{MM}$ below 2 standard deviations from the norm [6]. In 2010, the results of the European Consensus on sarcopenia (EWGSOP-1) were published, which presented its definitions, diagnostic criteria and classification [2]. On the basis of the causal relationship of sarcopenia with aging (or age), its primary form is distinguished, and with severe chronic diseases secondary [3]. In the practice of physicians, it is often difficult to identify the leading mechanism that led to low muscle mass in people older than 70 years, which often allows to recognize the combined etiology of sarcopenia $[1,5]$.

In 2018, the revised European criteria for sarcopenia (EWGSOP-2) were published, where the leading role was given to muscle strength, taking into account its greater clinical, social and prognostic significance. The following diagnosis algorithm is recommended [8]: verification of decreased muscle strength, verification of reduced muscle mass or quality, assessment of muscle performance. Reduced muscle strength is a prerequisite for the updated EWGSOP-2 criteria. EWGSOP-2 does not diagnose sarcopenia with preserved strength and sarcopenic muscle mass. However, loss of muscle mass remains a mandatory criterion for confirming sarcopenia [4].

The aim of the study was to increase the effectiveness of intensive care in patients with low sarcopenic index by improving the methods of influencing perioperative risk factors.

\section{Materials and methods}

The study was a clinical prospective open cohort randomized and was conducted on the basis of the Department of Anesthesiology and Intensive Care for patients of the surgical profile of the MNPE Kharkiv city clinical hospital of emergency aid named by prof. O.I. Meshchaninov and on the basis of the intensive care unit of the state institution Zaycev V.T. Institute of General and Emergency surgery of the National academy of medical sciences of Ukraine (2019-2020). To achieve this goal, 90 elderly patients (73.3 \pm 7.9 years) with surgical pathology of the abdominal cavity were examined who underwent emergency surgery under general anesthesia based on sodium thiopental with artificial ventilation, the average duration of which was $109.2 \pm 24.6 \mathrm{~min}$. The inclusion criteria were: age at least 60 years; absence of somatic diseases in the stage of decompensation, class II-III according to the ASA classification. According to the protocol of postoperative therapy, patients were divided into 3 randomized groups by age, sex, anthropometric data, volume and duration of surgery and concomitant comorbid background: group I, 30 patients ( 9 men, 21 women), mean 
age $72.4 \pm 6.1$ years, average height $161.2 \pm 10.4 \mathrm{~cm}$, average body weight $76.8 \pm 7.9 \mathrm{~kg}$, average duration of operation $109.4 \pm 31.1$ minutes; group II, 30 patients (10 men, 20 women), mean age $72.1 \pm 5.6$ years, mean height $164.4 \pm 12.1 \mathrm{~cm}$, mean body weight $78.4 \pm 6.7 \mathrm{~kg}$, mean duration of surgery $110.1 \pm 29.6 \mathrm{~min}$; group III, 30 patients ( 8 men, 22 women), mean age $72.2 \pm 5.9$ years, mean height $162.6 \pm 11.9 \mathrm{~cm}$, mean body weight $78.1 \pm 6.9 \mathrm{~kg}$, mean duration operation $109.8 \pm 32.2 \mathrm{~min}$.

Group I $(n=30)$ - patients who underwent standard intensive perioperative therapy, group II $(n=30)$ - standard intensive therapy with the addition of levocarnitine from the first day of stay in the intensive care unit $15 \mathrm{mg} / \mathrm{kg}$ body weight per day intravenously slowly; group III $(n=30)$ standard intensive care with the addition of levocarnitine from the first day of stay in the intensive care unit $15 \mathrm{mg} / \mathrm{kg}$ body weight per day intravenously slowly for 5 days and a solution of D-fructose-1,6-diphosphate sodium salt hydrate $150 \mathrm{mg} / \mathrm{kg} 2$ times a day intravenously at a rate of $10 \mathrm{ml}$ per minute for 5 days in the clinic.

By type of concomitant somatic pathology, patients were distributed as follows: hypertension 1-2 stage: 12 patients of group I, 14 patients of group II, 12 patients of group III; coronary heart disease: 17 patients of group I, 15 patients of group II, 14 patients of group III; heart failure I-IIA class: 22 patients of group I, 20 patients of group II, 18 patients of group III; type II diabetes mellitus: 28 patients of group I, 27 patients of group II, 27 patients of group III. All patients with confirmed type II diabetes mellitus at the time of admission received metformin $1827.2 \pm 236.1 \mathrm{mg}$ per day as antidiabetic therapy.

During the interview, the patient clarified the presence of complaints of impaired mobility, difficulty walking, getting up from a chair. Anamnestic data on the presence of falls and fractures in the anamnesis were evaluated. The diagnosis of sarcopenia was based on the recommendations proposed by the European Working Group on Sarcopenia in the Elderly (EWGSOP, 2009) [11]. The diagnosis was based on the determination of muscle mass, strength and function. When diagnosing sarcopenia, EWGSOP recommends the following criteria: decrease in muscle mass combined with decrease in muscle strength or muscle function. According to the EWGSOP recommendations, there are 3 stages of sarcopenia: presarcopenia, sarcopenia, severe sarcopenia [11]. Patients with a decrease in muscle mass index only have a stage of pre-sarcopenia; with a decrease in muscle mass and muscle strength, a stage of sarcopenia was established.

Muscle mass studies were performed immediately after surgery in the operating room using the method of bioimpedancemetry on the analyzer "MEDASS"ABC-02. After obtaining the results of skeletal muscle mass measurement in $\mathrm{kg}$, the musculoskeletal mass index (MSMI $(\mathrm{kg}) /$ height $(\mathrm{m} 2)=\mathrm{MSMl}, \mathrm{kg} / \mathrm{m} 2)$ was calculated . MSMI, corresponding to a decrease in muscle mass, was less than $6.75 \mathrm{~kg} / \mathrm{m} 2$.
The assessment of muscle strength was performed by the method of wrist dynamometry using a mechanical wrist dynamometer DK-25, the assessment of this indicator was performed taking into account the body mass index.

Enzyme-colorimetric method was used to determine such biochemical parameters of blood as urea, total protein, albumin and total cholesterol. Blood creatinine concentration was determined by the Jaffe kinetic method.

Serum cystatin $\mathrm{C}$ concentrations were determined by latex-enhanced immunoturbodimetry using a commercial kit of reagents and calibrators from DIALAB GmbH (Austria). The range of $0.7-1.2 \mathrm{mg} / \mathrm{L}$ was taken as the reference value.

Given that renal function may be reduced by more than $50 \%$ by the time the creatinine level exceeds the upper limit of normal, the use of cystatin $\mathrm{C}$ in laboratory diagnosis is due to the fact that it is a highly sensitive and accurate endogenous marker of glomerular filtration rate, and thus, pathology of the kidneys, its sensitivity is much higher than creatinine; highly sensitive marker of cardiovascular events, independent of such cardiomarkers as cardiac troponins, natriuretic peptides, C-reactive protein, etc. [7, 9].

Statistical processing of data entered in Excel spreadsheets was performed. The significance of the obtained data was checked using the Pearson $r$ correlation coefficient. All mathematical operations and graphical constructions were performed using the software packages "Microsoft Office XP": "Microsoft XP Home" and "Microsoft Excel XP" on a personal computer.

\section{Results}

It was important to determine the peculiarities of metabolism and muscle condition in patients at the time of admission to the surgical hospital, comparing these parameters with the level of biochemical markers and cystatin $C$ in the blood and the number of days in the intensive care unit depending on the intensive care algorithm (Table 1).

A correlation analysis of the dependence of the level of dysfunction of muscle tissue on the level of cystatin $C$ in the blood revealed a strong indirect correlation in all studied patients. Thus, in patients of group I, the decrease in muscle mass, which was determined by dynamometry and was on the 1st first day of stay in the clinic $16.2 \pm 1.2 \mathrm{~kg}$ had a strong indirect correlation, $r=-0.84$, with a concentration of cystatin $\mathrm{C}$ in the blood, $1.46 \pm 0.22 \mathrm{mg} / \mathrm{L}$. Identical dependence was observed in patients of groups II and III: $15.9 \pm 1.6 \mathrm{~kg}, 1.42 \pm 0.61 \mathrm{mg} / \mathrm{L}, \mathrm{r}=-0.82$ and $16.4 \pm 1.7 \mathrm{~kg}$, $1.41 \pm 0.49 \mathrm{mg} / \mathrm{L}, \mathrm{r}=-0.81$, respectively.

When determining the dependence of muscle strength on the concentration of cystatin $\mathrm{C}$ in the blood of patients of groups I, II and III at the time of admission to the surgical clinic was obtained a strong negative correlation in all patients: group I - a decrease in muscle strength was $67.2 \pm 3.1 \%$, the level of cystatin $C$ in the blood $1.46 \pm 0.22$ $\mathrm{mg} / \mathrm{L}-\mathrm{r}=-0.86$; group II - decrease in muscle strength was $65.8 \pm 5.2 \%$, the level of cystatin C $1.42 \pm 0.61 \mathrm{mg} / \mathrm{L}-\mathrm{r}=-0.84$; 
Table 1. Relationship between the functional state of muscle tissue and the level of vitamin B12 in the blood, $\mathrm{pg} / \mathrm{mL}(\mathrm{r})$.

\begin{tabular}{|c|c|c|c|}
\hline Indicators & $\begin{array}{l}\text { Group I } \\
(n=32)\end{array}$ & $\begin{array}{l}\text { Group II } \\
(n=32)\end{array}$ & $\begin{array}{c}\text { Group III } \\
(n=32)\end{array}$ \\
\hline Creatinine, $\mu \mathrm{mo} / \mathrm{L}$ & $87,4 \pm 6,2$ & $91,8 \pm 8,1$ & $89,2 \pm 7,4$ \\
\hline Cystatin C, mg/L & $1,46 \pm 0,22$ & $1,42 \pm 0,61$ & $1,41 \pm 0,49$ \\
\hline Urea, $\mu \mathrm{mol} / \mathrm{L}$ & $7,82 \pm 1,2$ & $7,94 \pm 0,9$ & $8,12 \pm 0,46$ \\
\hline Total protein, g/L & $66,1 \pm 6,4$ & $67,2 \pm 4,7$ & $66,4 \pm 6,2$ \\
\hline $\begin{array}{l}\text { Dynamometry (right hand, best } \\
\text { result in } 2 \text { attempts), } \mathrm{kg}\end{array}$ & $\begin{array}{l}16,2 \pm 1,2 \\
r=-0,84\end{array}$ & $\begin{array}{l}15,9 \pm 1,6 \\
r=-0,82\end{array}$ & $\begin{array}{r}16,4 \pm 1,7 \\
r=-0,81\end{array}$ \\
\hline $\begin{array}{l}\text { Decrease in muscle strength, } \\
(\%)\end{array}$ & $\begin{array}{l}67,2 \pm 3,1 \\
r=-0,86\end{array}$ & $\begin{array}{l}65,8 \pm 5,2 \\
r=-0,84\end{array}$ & $\begin{array}{c}66,1 \pm 4,9 \\
r=-0,82\end{array}$ \\
\hline $\begin{array}{l}\text { Number of days of treatment } \\
\text { in the intensive care unit }\end{array}$ & $5,4 \pm 1,1$ & $4,1 \pm 0,4$ & $3,2 \pm 0,2^{*|,|\|*|,|,\|}$ \\
\hline
\end{tabular}

Note. ${ }^{*}-p<0.05$ - probable difference between groups.

group III - decrease in muscle strength was $66.1 \pm 4.9 \%$, the level of cystatin $C$ in the blood $1.41 \pm 0.49 \mathrm{mg} / \mathrm{L}-\mathrm{r}=-0.82$

Identified correlations are important in the initial screening of patients for the appointment of an appropriate intensive care algorithm. Given the identified probable ( $p$ ?0.05) difference between the number of days that patients in each group were treated in the intensive care unit and the minimum number of patients in group III, who were prescribed a set of prevention of possible complications caused by initial pre-sarcopenia/sarcopenia

\section{References}

1. Bekfani, T., Pellicori, P., Morris, D. A., Ebner, N., Valentova, M., Steinbeck, L., ... \& von Haehling, S. (2016). Sarcopenia in patients with heart failure with preserved ejection fraction: impact on muscle strength, exercise capacity and quality of life. Int. J. Cardiol., 222, 41-46. doi: 10.1016/j.ijcard.2016.07.135

2. Calleja, M. A. R., Miquelez, A. A., Diez-Manglano, J., Gullon, A., Pose, A., Formiga, F., Mostaza, J. M., Cepeda, J. M., \& Suarez, C. (2019). Calleja Sarcopenia, frailty, cognitive impairment and mortality in elderly patients with non-valvular atrial fibrillation Rev. Clin. Esp., 219 (8), 424-432. doi: 10.1016/j.rce.2019.04.001

3. Canteri, A. L., Gusmon, L. B., Zanini, A. C., Nagano, F. E., E. I. Rabito, Petterle, R. R. ... \& Borba, V. Z. C. (2019). Sarcopenia in heart failure with reduced ejection fraction. Am. J. Cardiovasc. Dis., 9 (6), 116-126. Retrieved from https:// www.ncbi.nlm.nih.gov/pmc/articles/PMC6971421/

4. Cruz-Jentoft, A. J., Bahat, G., Bauer, J., Boirie ,Y., Bruyere, O., Cederholm, T., ... \& Zamboni, M. (2019). Sarcopenia: revised European consensus on definition and diagnosis. Age Ageing, 48 (1), 16-31. doi: 10.1093/ageing/afy169

5. de Souza, V. A., Oliveira, D., Barbosa, S. R., do Amaral Corr?a, J. O., Colugnati, F. A. B., Mansur, H. N., ... \& Bastos, M. G. (2017). Sarcopenia in patients with chronic kidney disease not yet on dialysis: analysis of the prevalence and associated factors. PloS One, 12 (4), e0176230. doi: 10.1371/ journal.pone. 0176230

6. dos Santos, L., Cyrino, E. S., Antunes, M., Santos, D. A., \&
- levocarnitine solution and solution of D-fructose-1,6diphosphate sodium salt of hydrate - the starting level of cystatin $\mathrm{C}$ in the blood can be considered a criterion for deciding on the appointment of an appropriate algorithm of intensive care in elderly patients with urgent surgical pathology.

\section{Conclusions and prospects for further development}

1. Decreased sarcopenic index, which is clinically reflected in a decrease in muscle mass and strength, is an important criterion for deciding on the composition of the intensive care unit in elderly patients with urgent surgical pathology, especially with concomitant chronic renal and/or heart failure.

2. Indicators of muscle mass and strength in the presarcopenic/sarcopenic state have an indirect strong correlation with the concentration of cystatin $C$ in the blood.

3 . The use of levocarnitine in intensive care and Dfructose-1,6-diphosphate solution of sodium hydrate is pathogenetically justified, as it reduces the number of days spent in the intensive care unit of elderly patients with urgent surgical pathology and improves their prognosis.

For further research, it is important to study the concentration of cystatin $\mathrm{C}$ in the dynamics of different variants of the complex of intensive care in elderly patients with clinical manifestations of reduced sarcopenic index.

Sardinha, L. B. (2017). Sarcopenia and physical independence in older adults: the independent and synergic role of muscle mass and muscle function. J. Cachexia Sarcopenia Muscle, 8 (2), 245-250. doi: 10.1002/jcsm.12160

7. Finney, H., Bates, C. J., \& Price, C. P. (1999). Plasma cystatin C determinations in a healthy elderly population. Arch. Gerontol. Geriatr., 29, 75-94.

8. Sandberg, C., Johansson, K., Christersson, C., Hlebowicz, J., Thilen, U., \& Johansson, B. (2019). Sarcopenia is common in adults with complex congenital heart disease. Int. J. Cardiol., 296, 57-62. doi: 10.1016/j.jjcard.2019.06.011

9. Wasen, E., Isoaho, R., Mattila, K., Vahlberg, T., Kivela, S-L., \& Irjala, K. (2004). Estimation of glomerular filtration rate in the elderly: a comparison of creatinine-based formulae with serum cystatin C. J. Intern. Med., 256 (1), 70-78. doi: 10.1111/j.13652796.2004.01340.x

10. Yeung, S. S. Y., Reijnierse, E. M., Pham, V. K., Trappenburg, M. C., Lim, W. K., Meskers, C. G. M., \& Maier, A. B. (2019). Sarcopenia and its association with falls and fractures in older adults: a systematic review and meta-analysis. J. Cachexia Sarcopenia Muscle, 10 (3), 485-500. doi: 10.1002/jcsm.12411

11. Yu, R., Leung, J., \& Woo, J. (2014). Incremental Predictive Value of Sarcopenia for Incident Fracture in an Elderly Chinese Cohort: Results From the Osteoporotic Fractures in Men (MrOs) Study. J. Am. Med. Dir. Assoc., 15 (8), 551-558. doi: 10.1016/ j.jamda.2014.02.005

РІВЕНЬ ЦИСТАТИНУ С ЯК ПРОГНОСТИЧНИЙ ФАКТОР РИЗИКУ ВИНИКНЕННЯ УСКЛАДНЕНЬ У ПІСЛЯОПЕРАЦІЙНОМУ ПЕРІОДІ У ХВОРИХ ПОХИЛОГО ВІКУ

Расенко А. В.

Анотація. Важливим критерієм оцінки перебігу ургентної хірургічної патології у хворих похилого віку є супутній стан саркопенії. Підвищений рівень у крові цистатину С, яких корелює зі зниженими показникам маси та сили м'язів, є важливим 
критерієм скринінгу при призначенні таким пацієнтам периопераційної інтенсивної терапії. Метою дослідження було підвищення ефрективності інтенсивної терапії у пацієнтів з низьким саркопенічним індексом шляхом вдосконалення методів впливу на періопераційні фактори ризику. Обстежено 90 хворих похилого віку (73,3土7,9 р.) з хірургічною патологією черевної порожнини, які перенесли екстрену операцію під загальною анестезією на основі тіопенталу натрію зі штучною вентиляцією легень. Пацієнтів розділили на 3 рандомізовані групи за віком, статтю, антропометричними даними, обсягом та тривалістю операції, супутнім коморбідним фоном та периопераційною інтенсивною терапією: I група (n=30) - пацієнти, які проходили стандартну інтенсивну періопераційну терапію, II група ( $n=30)$ - стандартну інтенсивну терапію з додаванням лівокарнітину; група III (n=30) - стандартну інтенсивну терапію з додаванням лівокарнітину та розчину D-фрруктози-1,6дифросфрату натрієвої солі гідрату. Визначали м'язову масу методом біоімпедансометрії на аналізаторі "MEDASS" ABC-02, проводили оцінку м'язової сили методом динамометрії зап'ястя, проводили розрахунок індексу м'язово-скелетної маси. Концентрацію цистатину C в сироватці крові визначали методом іммунотурбодіметрії з латексним посиленням ("DIALAB GmbH", Австрія). Значущість отриманих даних перевіряли за допомогою г-коефіцієнта кореляції Пірсона. Встановлено, що додаткове призначення левокарнітину та D-фруктози-1,6-дифосфрату натрієвої солі гідрату вірогідно зменшує кількість днів лікування у відділенні інтенсивної терапії, покращує прогноз, сприяє ранній активізації пацієнтів. Зміни метаболізму, які викликані зниженим саркопенічним індексом, потребують подальших досліджень.

Ключові слова: саркопенія, цистатин C, похилий вік, хірургічна патологія, інтенсивна терапія. 